\title{
The European Water Framework Directive facing current challenges: recommendations for a more efficient biological assessment of inland surface waters
}

\section{Ana Filipa Filipe, Maria João Feio, Aina Garcia-Raventós, José Pedro Ramião,} Giorgio Pace, Filipa MS Martins \& Maria Filomena Magalhães

To cite this article: Ana Filipa Filipe, Maria João Feio, Aina Garcia-Raventós, José Pedro Ramião, Giorgio Pace, Filipa MS Martins \& Maria Filomena Magalhães (2019) The European Water Framework Directive facing current challenges: recommendations for a more efficient biological assessment of inland surface waters, Inland Waters, 9:1, 95-103, DOI: 10.1080/20442041.2018.1494973

To link to this article: https://doi.org/10.1080/20442041.2018.1494973

Published online: 07 Nov 2018.

Џll Article views: 641

View Crossmark data $\longleftarrow$
Submit your article to this journal $\square$ 


\title{
The European Water Framework Directive facing current challenges: recommendations for a more efficient biological assessment of inland surface waters
}

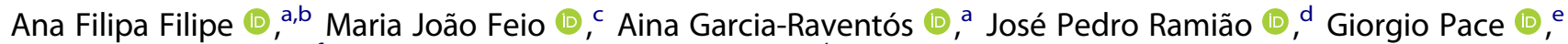 \\ Filipa MS Martins (i), a,f and Maria Filomena Magalhães (1) ${ }^{d}$ \\ ${ }^{\mathrm{a}} \mathrm{CIBIO} / \mathrm{InBIO}$, Centro de Investigação em Biodiversidade e Recursos Genéticos da Universidade do Porto, Vairão, Portugal; ${ }^{\mathrm{b}} \mathrm{CEABN} / \mathrm{InBio}, \mathrm{Centro}$ \\ de Ecologia Aplicada "Professor Baeta Neves," Instituto Superior de Agronomia, Universidade de Lisboa, Lisboa, Portugal; 'MARE-Marine and \\ Environmental Sciences Centre, Department of Life Sciences, Faculty of Sciences and Technology, University of Coimbra, Coimbra, Portugal; \\ ${ }^{d}$ CE3c, Centro de Ecologia, Evolução e Alterações Ambientais, Faculdade de Ciências, Universidade de Lisboa, Lisboa, Portugal; ${ }^{e}$ Centre of \\ Molecular and Environmental Biology (CBMA), Department of Biology, University of Minho, Campus de Gualtar, Braga, Portugal; ${ }^{f}$ Departamento \\ de Biologia, Faculdade de Ciências da Universidade do Porto, Porto, Portugal
}

\section{ABSTRACT}

High quality water is vital for human life, and ensuring its availability is a basic requirement and a major societal aim. The Water Framework Directive (WFD; 2000/60/EC) is a key piece of legislation for the protection and sustainable use of water in the European Union. In this work we briefly review the WFD directive and the current status of European inland surface waters. Additionally, we summarize major challenges and threats for the biological assessment of inland surface waters under climate change effects and invasion by alien species, and highlight the emerging tools and approaches that might help improve biological assessments, including molecular indices based on environmental DNA (eDNA), to new data from the Earth Observation programmes, and data-sharing platforms. Finally, we present recommendations to improve monitoring systems and assessments in the context of the WFD. Developments in this field may increase the likelihood of assuring high quality water for society.
ARTICLE HISTORY

Received 19 January 2018

Accepted 18 June 2018

\section{KEYWORDS}

environmental DNA; climate change; invasive alien species (IAS); rivers and lakes; water quality

\section{Introduction}

Currently the world is facing the problem of accessing enough high quality water to meet the needs of society. Despite the existence of efficient tools to monitor and manage surface waters, huge environmental challenges and threats are growing, and society must act rapidly to adjust to ongoing climate change and the consequent extreme eutrophication, floods, droughts, and biological invasions (Vörösmarty et al. 2010, IPCC 2014). Effective management of freshwater resources therefore remains a major global challenge in the 21st century (Jury and Vaux 2005, UN WWAP 2015).

The Water Framework Directive (WFD, Directive 2000/60/EC) has been the key piece of legislation for the protection and sustainable use of freshwater resources in the European Union since 2000. Its aim is to ensure a sufficient quantity of high quality water for societal and ecosystems needs (EEA 2018). The WFD is primary focused on environmental quality, replacing previous fragmented water policies focused on physical and chemical status, by adopting a holistic approach that considers ecological quality standards (Howarth
2006). The directive aims to expand the protection to all waters, including surface, ground, transitional, and coastal waters. It offers an integrated and coordinated approach to water management based on River Basin Management Plans (RBMPs), which include a costefficient programme of measures (POMs) at the basin level to achieve the objectives defined in the WFD (EU 2000). Specifically for surface waters, "good" ecological status is an evaluation of the biological community, hydromorphological characteristics, and chemical characteristics. Because no absolute standards for the biological quality can be set (i.e., the "good status" state), knowing the difference between the quality of a biological community and the expected status under minimal anthropogenic impacts (i.e., deviance from "reference conditions") indicates the need for management and implementation of a recovery plan (EU 2000). The preferred biological elements used by the directive are phytoplankton, phytobenthos, macrophytes, benthic macroinvertebrates, and fish, each of which is then classified into 5 quality classes (high, good, moderate, poor, and bad) and combined, such 
that the element with the worst status prevails (i.e., the so called "one-out, all-out" rule; EU 2000).

Major improvements in the quality of EU waters have been achieved during recent decades (EEA 2016), yet the WFD targets for achieving "good status" for all EU waters is far from being reached, despite the initial 2015 deadline (Reyjol et al. 2014, EEA 2016). The delay is certainty related to ongoing pressures, likely accentuated by climate change, especially drought events, and the establishment of invasive alien species (IAS; e.g., Voulvoulis et al. 2017).

Recent molecular advances allow rapid detection of species composition of the local communities using environmental DNA (eDNA) metabarcoding approaches (Weigand et al. 2017). Such technology will allow rapid taxonomic assessments and should facilitate WFD biological assessments. Earth observation programmes such as the EU Copernicus can access satellite data that characterize water in a high spatial and temporal resolution (Klein et al. 2017). Finally, tools for unifying and sharing large quantities of data are being developed (Boyd and Crawford 2012), and new science communication pathways are emerging with available online data and information (Brossard and Scheufele 2013). These advances might be pertinent during the planned 2019 revision of the WFD, especially considering the global environmental challenges.

In this research we asked: How can biological assessments be improved to support effective management of inland surface waters in the face of current environmental challenges? To address this issue we (1) analysed the current status of surface waters in Europe, (2) identified new environmental challenges, (3) reviewed cuttingedge technological and scientific advances that might improve the application of the WFD, and (4) provided recommendations on the opportunities associated with recent advances that might improve biological assessments and monitoring of inland surface waters.

\section{The European Water Framework Directive and the current status of surface waters}

Accurate assessment and monitoring of ecosystem health has become a priority of global environmental programmes, and regulations around the globe have been adopted to improve water quality (UN-Water 2015). The WFD was the first European Directive focusing on environmental sustainability, with the main target to achieve good ecological status of all waterbodies and stop deterioration of waterbody status by 2015 . The WFD implementation requires the EU members states to assess and monitor the ecological and chemical status of their waterbodies and further maintain or restore them to achieve a good status (EC 2012). During the past decade, a large investment was put into developing biological assessment methods comparable across member states (Feio et al. 2016). Indeed, great effort has been put into developing metrics and indices compliant with the WFD (Birk et al. 2012), substituting old indices with methods that integrate the structure of communities and the regional and typological variability of streams. As a consequence of the diversity of methods developed, the comparability of evaluations had to be assured through intense collaborative work among countries under the so-called intercalibration exercise (e.g., Sandin and Hering 2004, Poikane et al. 2011, Feio et al. 2014).

Despite all efforts toward WFD monitoring and implementation, only $41 \%$ of surface waterbodies evaluated are in good or high ecological status according to the second RBMPs reported in 2015, and limited improvements are expected from 2016 to 2021 (EEA 2018; Fig. 1). According to the report, the ecological status of rivers and transitional waters is, on average, lower than that of lakes and coastal waters (EEA 2018). In some river basin districts located in northern Europe (Netherlands, Germany, and Belgium), $>90 \%$ of rivers and lakes have less than good ecological status while in southern Europe the percentage is $30-50 \%$, with some reaching $70-90 \%$ in Portugal, Spain, and Greece (EEA 2018; Fig. 1 ). The general pattern is similar for coastal and transitional waters, with the highest percentages of less than good ecological status in northern Europe (EEA 2018). During the past 30 years, however, pollution has been reduced in numerous waterbodies through wastewater treatment improvements and decreased nitrogen and phosphorus inputs from agricultural sources (EEA 2018). Although the average nitrate and phosphate concentration in European rivers declined 0.8\% and 2.1\% per year, respectively, between 1992 and 2012 (EEA 2015a), pollution from urban and industrial wastewater and agriculture remains high (EEA 2015b).

\section{The new environmental challenges: climate change and invasive species}

Inland water resources are affected by multiple stressors, including urban and agricultural land use and hydropower generation, but also by more recent environmental drivers such as climate change and IAS (Hering et al. 2015). The impact of these factors is likely to grow in the next decades, along with the increasing demand for clean water as it decreases in availability (Brownlie et al. 2017). Hence, knowing the potential consequences of climate change and IAS in the ecosystem and forecasting how they influence biological assessment 


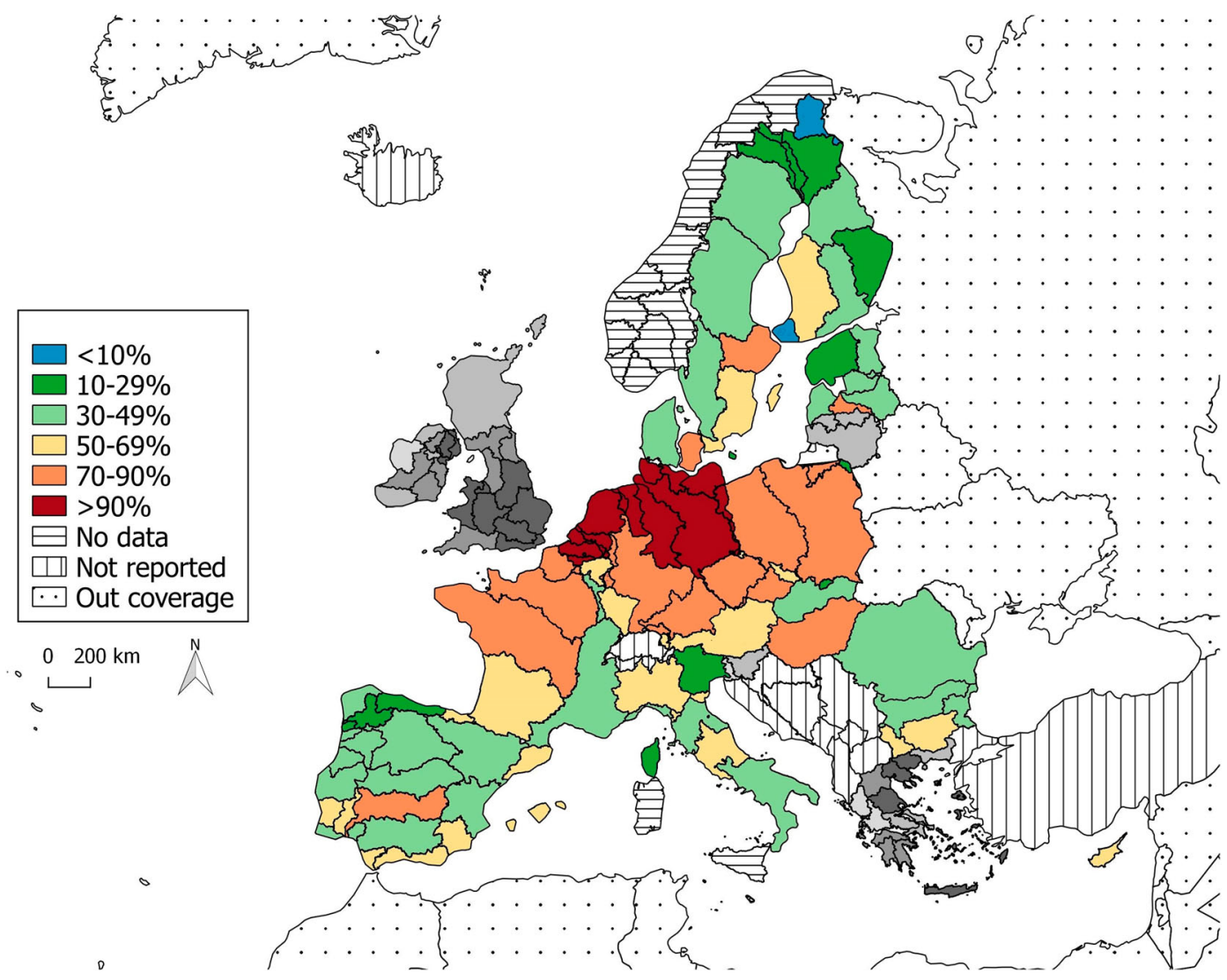

Figure 1. Percentage of waterbodies in different river basin districts classified with less than "good" ecological status in rivers and lakes. Adapted from European Environment Agency, 2016 version; http://www.eea.europa.eu/legal/copyright.

of surface waters is crucial for more efficient biotic assessment and monitoring of inland surface waters (Jackson et al. 2001, Reyjol et al. 2014).

Climate change leads to warmer waters, which can intensify the symptoms of eutrophication in freshwaters, increase the risk of elevated nutrient inputs and concentration, and promote methane emissions, especially during summer (Jeppesen et al. 2010, Bastviken et al. 2011, Brookshire et al. 2011). As mean temperature increases, the volume of snowpack decreases, altering the time of release and changing the runoff patterns. This problem will be especially serious in regions where water supplies depend on snowpack, such as Northern Europe (Jury and Vaux 2005). Additionally, sea-level rise is expected to extend salinized areas in groundwaters and estuaries, decreasing freshwater availability for humans and ecosystems (Quevauviller 2011). Future spatial and seasonal distribution of fresh waters will be altered between high and low latitudes. In northern European latitudes, high precipitation and floods will be major concerns while extreme droughts are expected in southern areas with Mediterranean climates (IPCC 2014). The Mediterranean Basin typically hosts a high level of endemic species and is considered one of the most important hotspots of freshwater biodiversity (Hermoso et al. 2009, De Figueroa et al. 2013, Filipe et al. 2013); however, it is among the most vulnerable ecosystems worldwide to the effects of ongoing climate change and consequent extreme events of floods and droughts (Filipe et al. 2013). Dramatic shifts in the hydrological patterns of fluvial ecosystems are projected to lead to unpredictable harsh events, exacerbated water stress, and landscape desertification (IPCC 2014). These events already represent the most common natural disasters in Europe and are a major societal concern (Bradford et al. 2012).

The increasing number and expansion of IAS in freshwater ecosystems has replaced native biota in recent years, dramatically changing aquatic biodiversity and ecosystem structure and functioning (Cardoso and Free 2008) and degrading aquatic services (Mota et al. 2014). Invasive species may alter the water quality (McCormick et al. 2010), as in the case of the zebra mussel (Dreissena polymorpha), with consequent impacts on water supply facilities and biotic indices (Minchin et al. 2002, Zaiko and Daunys 2015). Moreover, surface waters can be vectors for the spread of diseases, such as sudden oak death (Grünwald et al. 2012), incurring major 
economic and ecological costs for the control of invasive species.

Climate changes are expected to modify the ecological impacts of IAS by enhancing their competitive and predatory effects on native species and by increasing the virulence of some diseases. But such interactions are complex, and how biota will respond to these novel environmental conditions is uncertain (Rahel and Olden 2008). To face the environmental challenges, timely and efficient environmental monitoring is needed (Hellmann et al. 2008).

\section{New tools and approaches for biological assessment}

As the 2019 revision of the WFD approaches, emerging tools are being developed that could potentially produce timely and accurate assessments to address the ongoing multiple stressors. Recently developed eDNA and metabarcoding are potentially useful tools to monitor aquatic biological status and detect species, including those threatened and nonnative (e.g., Leese et al. 2016, Valentini et al. 2016, Weigand et al. 2017). These techniques identify short DNA sequences of the organisms present in samples of biological communities (e.g., bulk of macroinvertebrates, arthropods) or environmental samples (e.g., eDNA from water, soil, feaces). While these tools clearly generate important data for biological assessments, application is still in the early stages. Yet, these approaches could reduce the time and costs required, especially during fieldwork and processing of samples. For instance, a water sample may contain residual DNA from organisms inhabiting a certain habitat, while in the laboratory the high-throughput sequencing rapidly generates lists of organisms at a high taxonomic resolution. The method can provide a general overview of the species present in a waterbody, including those from watercourses upstream, but currently only provides relative abundances, is less efficient for some taxa, and does not provide accurate information about the state of viable populations. The DNAqua-Net COST action initiative currently links scientists across Europe and beyond to gather existing knowledge and overcome the current limitations for the implementation of the novel DNA-based approaches for biological assessments (Weigand et al. 2017, Pawlowski et al. 2018).

Remote sensing using satellite platforms could potentially provide an invaluable complementary source of data with a higher spatial coverage and temporal frequency useful for monitoring the ecological status for the WFD (Palmer et al. 2015). The European Space Agency's Copernicus Programme is part of the European Earth Observation initiative established in 1998 (Balzter
2017). The open and accessible Copernicus next-generation satellite data in combination with interactive cloud-processing of data has enormous application potential in environmental monitoring. This initiative is already delivering many core monitoring services for oceans, land surface, air quality, polar ice sheets, among others, and aspires to provide long-term observations of critical parameters from space (Balzter 2017). For inland water monitoring, some technical challenges have been solved in recent years (Palmer et al. 2015). For example, satellite remote sensing has been used to map optically active water quality parameters of lakes, rivers, transitional, and coastal waters, such as chlorophyll $a$ (a proxy for phytoplankton biomass and blooms), measures of water transparency, temperature, total suspended matter, turbidity, and coloured dissolved organic matter (Palmer et al. 2015, Tyler et al. 2016, Balzter 2017). Further effort will be required to quantify and better constrain the uncertainties on the performance of in-water models and algorithms in the different optical water types (Tyler et al. 2016). Undoubtedly, the new Earth Observation datasets provide an opportunity to better understand the response and sensitivity of surface waters to natural and anthropogenic pressures.

Data sharing platforms and online tools have been developed across EU countries. This next generation of merging and sharing data, together with the rapid improvements in computing power, will bring new insights into such data, specifically regarding environmental changes occurring within and across the catchment and the resulting downstream impacts on the highly dynamic transitional and coastal environments (Beniston et al. 2012, Tyler et al. 2016, Klein et al. 2017).

\section{Recommendations}

For the 2019 WFD review, and considering the current environmental challenges, we present some recommendations that may improve biological assessments and monitoring and, consequently, lead to effective management of surface waters:

\section{Integrate biogeography into biological assessments}

Differences in the distribution of biotic indicators are expected based on biogeographical riverscape contexts. For example, in European southern temporary streams, species occurring in pristine habitats are typically resistant and resilient to stress due to seasonal drought events, and therefore pristine reference conditions need to address natural stresses (e.g., Sánchez-Montoya et al. 2010). We recommend building regionalization maps 
for Europe that predict the occurrence of biota on pristine or near-pristine sites (i.e., using reference conditions). The biotic responses to the variability associated with the hydroclimatology could therefore be quantified, and the deviation of a particular waterbody from the reference values of selected metrics could be calculated and compared among distinct regions and river types. Predictions for macroinvertebrates under climate change have already been developed, thus showing the potential of these methods to predict the distribution of species and communities (e.g., Domisch et al. 2013).

\section{Account for the stream network arrangement}

The "ecological status" of a stream reach is highly dependent on input from the stream network, especially from upstream (e.g., invasive species dispersal, pharmaceuticals, organic pollution; Gros et al. 2007, Filipe et al. 2017), but the WFD biological assessments do not consider the spatial autocorrelation within stream networks (EC 2009). We recommend the use of spatial software tools that account for the influences upstream to downstream so the source of pressures upstream, impacts downstream, and expansion or contraction of populations can be quantified (e.g., SNN R package, RivTools software; Ver Hoef and Peterson 2010, Ver Hoef et al. 2014, Duarte et al. 2016). The use of these tools will help predict, for example, how far substances can travel and in what concentrations, if conditions are favorable for the spread of invasive alien species, or how much a pollution source or a protected area upstream influence the biological assessment downstream (e.g., Filipe et al. 2017).

\section{Revise the "one-out, all-out" principle}

Assessing the "biological status" under the WFD is based on an integrative approach whereby multiple indicators are used to measure the deviations of the biological communities from undisturbed reference conditions. With the one-out, all-out principle, a specific waterbody with even one parameter that falls below expectations may be classified below "good" status, even if it is not, thus inflating type I errors (e.g., Borja and Rodriguez 2010). This approach risks imposing unnecessary restoration measures, which impact the cost of implementing the WFD (e.g., Prato et al. 2014, Voulvoulis et al. 2017). We recommend testing the alternative combination rules previously proposed (e.g., Borja et al. 2009), as well as mapping estimates of type I and type II errors, as highlighted by Hering et al. (2010). We also recommend focusing on measures of change in the classification of the waterbodies over time and not on absolute measures, a focus that might better fit the aim and vision of the WFD, in which the status of waterbodies should not deteriorate.

\section{Account for effects of climate change}

Climate change impacts water quality and the inhabiting biota (Do Ó 2007, Whitehead et al. 2009, Filipe et al. 2013) and influences WFD reference conditions (Wilby et al. 2006). We recommend the integration of predictions and risks associated with climate change in the biotic assessment, particularly in the definition of reference conditions for each region. This step is particularly relevant in regions where severe changes are predicted. Future hydrology can be predicted under climate change scenarios, such as the relative change in frequency of flood and drought events (e.g., based on the global integrated water model WaterGAP; Alcamo et al. 2003a, 2003b) and recurrence. For example, both flood and drought events are predicted to occur every 10-50 years by the 2070s in southern and southeastern Europe (Lehner et al. 2006).

\section{Account for invasive alien species (IAS)}

IAS, together with habitat degradation, pose a major threat to biotic communities (IUCN 2000). IAS establishment can lead to ecological degradation and lower biological status, but it can also confound the interpretation of some established assessment metrics (e.g., total species richness; Cardoso and Free 2008). Although the WFD does not specifically consider IAS, some plans have begun to incorporate them, initially as a way to measure human disturbances rather than the impact of the IAS themselves (e.g., Borja et al. 2006, Matono et al. 2009, Hermoso et al. 2010). We recommend IAS be systematically incorporated into WFD assessments because of their potential to significantly alter aquatic ecosystem structure and functioning. A possible framework could be to consider IAS a pressure that increases the risk of failing to achieve good ecological status and as a metric of biotic degradation (Borja et al. 2006, Cardoso and Free 2008, Matono et al. 2009).

\section{Validate new assessment approaches: eDNA metabarcoding and Earth Observations}

Emerging tools can be potentially useful to assess biological status of surface waters and monitor them with a fine resolution (temporal and spatial) once the previous referred limitations are overcome. Molecular tools such as eDNA and metabarcoding (Valentini et al. 2016, Weigand et al. 2017) and Earth Observation datasets be useful 
for biological assessments and estimating water parameters parameters (chlorophyll $a$, total suspended matter, and coloured dissolved organic matter; Klein et al. 2017). We recommend investigating the potential use of these tools to assess biological status response to current environmental changes and to validate data. For example, aquatic invasive species detection is laborious in terms of costs and time, but eDNA molecular tools could overcome these limitations, complementing and extending conventional surveys (Mächler et al. 2014). Moreover, currently available satellite-based methods can quantify water quality parameters at larger spatial and temporal scales. For example, frequency of cyanobacterial algal blooms could help prioritize locations with more exposure to blooms (Clark et al. 2017).

\section{Implement data information systems}

Currently, all EU member states produce monitoring information and assessments of surface waters. Simultaneously, monitoring of nature conservation and protected areas generates vast datasets about the inhabiting biota, yet the information is often restricted in reports from different institutions. We recommend implementing data information systems simultaneously adapted to the needs of each region and standardized among regions so that river basin management planning can be easily and quickly consulted. These information systems should form the basis of proper riverscape management at the regional scale, useful for management and prioritization of ecosystem services from agriculture to water (e.g., Coppens et al. 2015, Jones et al. 2017). Furthermore, because many European river basins are international, a common understanding and approach crossing administrative and territorial borders is needed. The necessity and guidelines for such a framework were recently addressed for the successful and effective implementation of the EU environment aims regarding water (EC 2016).

\section{Foster public participation}

The WFD requires public participation in its planning process to deal with the inherent complexity of water resources management and the integration of multiple perspectives and skills for policy-making in freshwater governance (Steyaert and Ollivier 2007). We recommend including all interested stakeholders' multiple perspectives and uses, which is vital for the WFD implementation and decision making (Voulvoulis et al. 2017), through emerging communication pathways such as the internet, mobile technology, and social media. Communication pathways are shifting to online media as the primary source of information and could be used for public participation (Brossard and Scheufele 2013). Stronger communication between managers, scientists, and general public is needed to support the WFD implementation (Cash et al. 2003). Citizen science has been a promising tool for stakeholder awareness (e.g., Crall et al. 2013). Finally, communication could also be facilitated by open access data policies.

\section{Conclusions}

The WFD faces rising challenges due to climate change and the spread and establishment of IAS, but it also can take advantage of technological and scientific advances from molecular biology to Earth Observation platforms. Our recommendations on meeting such challenges and benefiting from these advances should provide an interesting basis for achieving the aims of the WFD.

\section{ORCID}

Ana Filipa Filipe (D) http://orcid.org/0000-0001-7862-2676

Maria João Feio (D) http://orcid.org/0000-0003-0362-6802

Aina Garcia-Raventós (i) http://orcid.org/0000-0003-2373$179 \mathrm{X}$

José Pedro Ramião (D) http://orcid.org/0000-0001-9713-5179 Giorgio Pace (D) http://orcid.org/0000-0003-4231-5644

Filipa MS Martins (D) http://orcid.org/0000-0003-4191-5031

Maria Filomena Magalhães (D) http://orcid.org/0000-00017308-2279

\section{Acknowledgements}

This article was supported by and prepared under the FRESHING Project funded by the Portuguese Foundation for Science and Technology (FCT) and COMPETE (PTDC/AAG-MAA/ 2261/2014 - POCI-01-0145-FEDER-356 016824). AFF, AGR, and JPR were supported by FRESHING. FMSM was supported by FCT grant SFRH/BD/104703/2014. MJF was supported by the strategic project UID/MAR/04292/2013 granted to MARE. We are grateful to reviewers and editor for their very helpful advice and critical comments.

\section{References}

Alcamo J, Döll P, Henrichs T, Kaspar F, Lehner B, Rösch T, Siebert S. 2003a. Development and testing of the WaterGAP 2 global model of water use and availability. Hydrol Sci J. 48:317-337.

Alcamo J, Döll P, Henrichs T, Kaspar F, Lehner B, Rösch T, Siebert S. 2003b. Global estimates of water withdrawals and availability under current and future "business-asusual” conditions. Hydrol Sci J. 48:339-349.

Balzter H. 2017. Earth observation for land and emergency monitoring. Earth observation for land and 
emergency monitoring core services. Chichester (UK): Wiley; p. 1-2.

Bastviken D, Tranvik LJ, Downing JA, Crill PM, Enrich-Prast A. 2011. Freshwater methane emissions offset the continental carbon sink. Science. 331:50.

Beniston M, Stoffel M, Harding R, Kernan M, Ludwig R, Moors E, Samuels P, Tockner K. 2012. Obstacles to data access for research related to climate and water: implications for science and EU policy-making. Environ Sci Policy. 17:41-48.

Birk S, Bonne W, Borja Á, Brucet S, Courrat A, Poikane S, Solimini A, Van De Bund W, Zampoukas N, Hering D. 2012. Three hundred ways to assess Europe's surface waters: an almost complete overview of biological methods to implement the Water Framework Directive. Ecol Indic. 18:31-41.

Borja Á, Bald J, Franco J, Larreta J, Muxika I, Revilla M, Rodríguez JG, Solaun O, Uriarte A, Valencia V. 2009. Using multiple ecosystem components, in assessing ecological status in Spanish (Basque Country) Atlantic marine waters. Mar Pollut Bull. 59:54-64.

Borja Á, Galparsoro I, Solaun O, Muxika I, Tello EM, Uriarte A, Valencia V. 2006. The European Water Framework Directive and the DPSIR, a methodological approach to assess the risk of failing to achieve good ecological status. Estuar Coast Shelf Sci. 66:84-96.

Borja Á, Rodríguez JG. 2010. Problems associated with the 'one-out, all-out' principle, when using multiple ecosystem components in assessing the ecological status of marine waters. Mar Pollut Bull. 60:1143-1146.

Boyd DM, Crawford K. 2012. Critical questions for big data. Inform Commun Soc. 15:662-679.

Bradford RA, O’Sullivan JJ, Van Der Craats IM, Krywkow J, Rotko P, Aaltonen J, Bonaiuto M, De Dominicis S, Waylen K, Schelfaut K. 2012. Risk perception - issues for flood management in Europe. Nat Hazard Earth Syst Sci. 12:2299-2309.

Brookshire ENJ, Gerber S, Webster JR, Vose JM, Swank WT. 2011. Direct effects of temperature on forest nitrogen cycling revealed through analysis of long-term watershed records. Glob Chang Biol. 17:297-308.

Brossard D, Scheufele DA. 2013. Science, new media, and the public. Science. 339:40-41.

Brownlie WJ, Woods HJ, Waters KE, Moore AL, Bruce AM, Olszewska JP, Ives SC. 2017. Freshwater science for the benefit of society: a perspective from early career researchers. Inland Waters. 7:227-235.

Cardoso AC, Free G. 2008. Incorporating invasive alien species into ecological assessment in the context of the Water Framework Directive. Aquat Invasions. 3:361-366.

Cash DW, Clark WC, Alcock F, Dickson NM, Eckley N, Guston DH, Jäger J, Mitchell RB. 2003. Knowledge systems for sustainable development. $\mathrm{P}$ Nat Acad Sci USA. 100:8086-8091.

Clark JM, Schaeffer BA, Darling JA, Urquhart EA, Johnston JM, Ignatius AR, Myer MH, Loftin KA, Werdell PJ, Stumpf RP. 2017. Satellite monitoring of cyanobacterial harmful algal bloom frequency in recreational waters and drinking water sources. Ecol Indic. 80:84-95.

Coppens LJ, van Gils JA, Ter Laak TL, Raterman BW, van Wezel AP. 2015. Towards spatially smart abatement of human pharmaceuticals in surface waters: defining impact of sewage treatment plants on susceptible functions. Water Res. 81:356-365.

Crall AW, Jordan R, Holfelder K, Newman GJ, Graham J, Waller DM. 2013. The impacts of an invasive species citizen science training program on participant attitudes, behavior, and science literacy. Public Underst Sci. 22:745-764.

De Figueroa JMT, López-Rodríguez MJ, Fenoglio S, SánchezCastillo P, Fochetti R. 2013. Freshwater biodiversity in the rivers of the Mediterranean Basin. Hydrobiologia. 719:137-186.

Domisch S, Araújo MB, Bonada N, Pauls SU, Jähnig SC, Haase P. 2013. Modelling distribution in European stream macroinvertebrates under future climates. Glob Chang Biol. 19:752-762.

Do Ó A. 2007. Drought risk management in the Mediterranean under the Water Framework Directive the example of Algarve (Portugal). WIT Trans Ecol Envir. 103:81-90.

Duarte G, Oliveira T, Segurado P, Branco P, Haidvogl G, Pont D, Ferreira MT. 2016. River Network Toolkit (RivTool) - a new software for river networks. CCM2 River and Catchment Database for Europe - Applications Workshop in the 19th AGILE International Conference on Geographic Information Science. Helsinki (Finland).

[EC] European Commission. 2009. Common implementation strategy water framework directive. Guidance document No. 24. River basin management in a changing climate. Brussels (Belgium).

[EC] European Commission. 2012. Report from the commission to the European Parliament and the council on the Implementation of the Water Framework Directive (2000/ 60/EC). Brussels (Belgium): River Basin Management Plans. COM (2012) 670 final.

[EC] European Commission. 2016. Common implementation strategy for the water framework directive and the floods directive: guidelines on integrating water reuse into water planning and management in the context of the WFD. Amsterdam (Netherlands); [accessed 2018 Jan 18]. http:// ec.europa.eu/environment/water/

[EEA] European Environment Agency. 2015a. Nutrients in freshwater. CSI 020, WAT 003; [accessed 2018 Jan 10]. https://www.eea.europa.eu/data-and-maps/indicators/nutr ients-in-freshwater/nutrients-in-freshwater-assessment-pu blished-6

[EEA] European Environment Agency. 2015b. The European environment - state and outlook 2015. Copenhagen (Denmark); [accessed 2018 January 10]. https://www.eea. europa.eu/soer\#tab-synthesis-report

[EEA] European Environment Agency. 2016. Surface waters. Environmental Indicator Report AIRS; [accessed 2018 Jan 10]. https://www.eea.europa.eu/airs/2016/natural-capital/ surface-waters

[EEA] European Environment Agency. 2018. Surface waters; [accessed 2018 Jan 10]. https://www.eea.europa.eu/airs/ 2017/natural-capital/copy_of_surface-waters\#tab-basedon-indicators

[EU] European Union. 2000. Directive 2000/60/EC of October 23, 2000, of the European parliament and of the council establishing a framework for community action in the field of water policy. Official J Eur Community. L327:1-72.

Feio MJ, Calapez AR, Elias CL, Cortes RMV, Graça MAS, Pinto P, Almeida SFP. 2016. The paradox of expert 
judgment in rivers ecological monitoring. J Environ Manage. 184:609-616.

Feio MJ, Ferreira J, Buffagni A, Erba S, Dörflinger G, Ferréol M, Munné A, Prat N, Tziortzis I, Urbanic G. 2014. Comparability of ecological quality boundaries in the Mediterranean basin using freshwater benthic invertebrates. Statistical options and implications. Sci Total Environ. 476:777-784.

Filipe AF, Lawrence JE, Bonada N. 2013. Vulnerability of stream biota to climate change in Mediterranean climate regions: a synthesis of ecological responses and conservation challenges. Hydrobiologia. 719:331-351.

Filipe AF, Quaglietta L, Ferreira M, Magalhães MF, Beja P. 2017. Geostatistical distribution modelling of two invasive crayfish across dendritic stream networks. Biol Invasions. 19:2899-2912.

Gros M, Petrović M, Barcelo D. 2007. Wastewater treatment plants as a pathway for aquatic contamination by pharmaceuticals in the Ebro river basin (northeast Spain). Environ Toxicol Chem. 26:1553-1562.

Grünwald NJ, Garbelotto M, Goss EM, Heungens K, Prospero S. 2012. Emergence of the sudden oak death pathogen Phytophthora ramorum. Trends Microbiol. 20:131-138.

Hellmann JJ, Byers JE, Bierwagen BG, Dukes JS. 2008. Five potential consequences of climate change for invasive species. Conserv Biol. 22:534-543.

Hering D, Borja Á, Carstensen J, Carvalho L, Elliott M, Feld CK, Heiskanen AS, Johnson RK, Moe J, Pont D, et al. 2010. The European Water Framework Directive at the age of 10: a critical review of the achievements with recommendations for the future. Sci Total Environ. 17:149-160.

Hering D, Carvalho L, Argillier C, Beklioglu M, Borja Á, Cardoso AC, Duel H, Ferreira MT, Globevnik L, Hanganu J, et al. 2015. Managing aquatic ecosystems and water resources under multiple stress - an introduction to the MARS project. Sci Total Environ. 503:10-21.

Hermoso V, Clavero M, Blanco-Garrido F, Prenda J. 2010. Assessing the ecological status in species-poor systems: a fish-based index for Mediterranean Rivers (Guadiana River, SW Spain). Ecol Indic. 10:1152-1161.

Hermoso V, Linke S, Prenda, J. 2009. Identifying priority sites for the conservation of freshwater fish biodiversity in a Mediterranean basin with a high degree of threatened endemics. Hydrobiologia. 623:127-140.

Howarth W. 2006. The progression towards ecological quality standards. J Environ Law. 18:3-35.

[IPCC] Intergovernmental Panel on Climate Change. 2014. Climate change 2014: impacts, adaptation, and vulnerability. Contribution of Working Group II to the Fifth Assessment Report of the IPCC. In: Field CB, Barros VR, Dokken DJ, Mach KJ, Mastrandrea MD, et al., editors. Summary for policymakers. Cambridge (UK): Cambridge University Press; p. 1-32.

[IUCN] International Union for the Conservation of Nature. 2000. IUCN guidelines for the prevention of biodiversity loss caused by alien invasive species. 51st meeting of the IUCN Council. Gland (Switzerland): Species Survival Commission; [accessed 2018 January 10]. http://www. iucn.org/themes/ssc/publications/policy/invasivesEng.htm

Jackson RB, Carpenter SR, Dahm CN, McKnight DM, Naiman RJ, Postel SL, Running SW. 2001. Water in a changing world. Ecol Appl. 11:1027-1045.
Jeppesen E, Moss B, Bennion H, Carvalho L, De Meester L, Feuchtmayr H, Friberg N, Gessner MO, Hefting M, Lauridsen TL, et al. 2010. Interaction of climate change and eutrophication. In: Kernan M, Battarbee RW, Moss B, editors. Climate change impacts on freshwater ecosystems. Chichester (UK): Wiley; p. 119-151.

Jones JI, Murphy JF, Anthony, SG, Arnold A, Blackburn JH, Duerdoth CP, Hawczak A, Hughes GO, Pretty JL, Scarlett PM, Gooday RD. 2017. Do agrienvironment schemes result in improved water quality? J Appl Ecol. 54:537-546.

Jury WA, Vaux H. 2005. The role of science in solving the world's emerging water problems. P Nat Acad Sci USA. 102:15715-15720.

Klein T, Nilsson M, Persson A, Håkansson B. 2017. From open data to open analyses - new opportunities for environmental applications? Environments. 4:32.

Leese F, Altermatt F, Bouchez A, Ekrem T, Hering D, Meissner K, Mergen P, Pawlowski J, Piggott JJ, Rimet F, et al. 2016. DNAqua-Net: developing new genetic tools for bioassessment and monitoring of aquatic ecosystems in Europe. RIO. 2:e11321.

Lehner B, Döll P, Alcamo J, Henrichs T, Kaspar F. 2006. Estimating the impact of global change on flood and drought risks in Europe: a continental, integrated analysis. Clim Change. 75:273-299.

Mächler E, Deiner K, Steinmann P and Altermatt F. 2014. Utility of environmental DNA for monitoring rare and indicator macroinvertebrate species. Freshwater Sci 33:1174-1183.

Matono P, Ilhéu M, Formigo N, Ferreira MT, Almeida PR, Cortes R, Bernardo J. 2009. Development of a fish index for the rivers of continental Portugal. Recursos Hídricos. 90:77-84.

McCormick FH, Contreras, GC and Johnson SL. 2010. Effects of nonindigenous invasive species on water quality and quantity. In: Dix M, Britton K, editors. A dynamic invasive species research vision: opportunities and priorities. 2009-29.

Minchin D, Lucy F, Sullivan M. 2002. Zebra mussel: impacts and spread. In: Invasive aquatic species of Europe. Distribution, impacts and management. Dordrecht (Netherlands): Springer; p. 135-146.

Mota M, Sousa RG, Araújo J, Braga C, Antunes C. 2014. Ecology and conservation of freshwater fish: time to act for a more effective management. Ecol Freshw Fish. 23:111-113.

Palmer SC, Kutser T, Hunter PD. 2015. Remote sensing of inland waters: challenges, progress and future directions. Remote Sens Environ. 157:1-8.

Pawlowski J, Kelly-Quinn M, Altermatt F, Apothéloz-PerretGentil L, Beja P, Boggero Borja Á, Bouchez A, Cordier T, Domaizon I, et al. 2018. The future of biotic indices in the ecogenomic era: integrating DNA metabarcoding in biological assessment pf aquatic ecosystems. Sci Total Environ. 637-638:1295-1310.

Poikane S, van den Berg M, Hellsten S, de Hoyos C, OrtizCasas J, Pall K, Portielje R, Phillips G, Solheim AL, Tierney D, et al. 2011. Lake ecological assessment systems and intercalibration for the European Water Framework Directive: aims, achievements and further challenges. Procedia Environ Sci. 9:153-168. 
Prato S, La Valle P, De Luca E, Lattanzi L, Migliore G, Morgana JG, Munari C, Nicoletti L, Izzo G, Mistri M. 2014. The "one-out, all-out" principle entails the risk of imposing unnecessary restoration costs: a study case in two Mediterranean coastal lakes. Mar Pollut Bull. 80:30-40.

Quevauviller P. 2011. Adapting to climate change: reducing water-related risks in Europe-EU policy and research considerations. Environ Sci Policy. 14:722-729.

Rahel FJ, Olden JD. 2008. Assessing the effects of climate change on aquatic invasive species. Conserv Biol. 22:521-533.

Reyjol Y, Argillier C, Bonne W, Borja Á, Buijse AD, Cardoso, AC, Daufresne M, Kernan M, Ferreira MT, Poikane S, et al. 2014. Assessing the ecological status in the context of the European Water Framework Directive: Where do we go now? Sci Total Environ. 497:332-344.

Sánchez-Montoya MM, Vidal-Abarca MR, Suárez ML. 2010. Comparing the sensitivity of diverse macroinvertebrate metrics to a multiple stressor gradient in Mediterranean streams and its influence on the assessment of ecological status. Ecol Indic. 10:896-904.

Sandin L, Hering D. 2004. Comparing macroinvertebrate indices to detect organic pollution across Europe: a contribution to the EC Water Framework Directive intercalibration. Hydrobiologia. 516:55-68.

Steyaert P, Ollivier G. 2007. The European Water Framework Directive: how ecological assumptions frame technical and social change. Ecol Soc. 12:25.

Tyler AN, Hunter PD, Spyrakos E, Groom S, Constantinescu AM, Kitchen J. 2016. Developments in Earth observation for the assessment and monitoring of inland, transitional, coastal and shelf-sea waters. Sci Total Environ. 572:1307-1321.

Valentini A, Taberlet P, Miaud C, Civade R, Herder J, Thomsen PF, Bellemain E, Besnard A, Coissac E, Boyer F, et al. 2016. Next-generation monitoring of aquatic biodiversity using environmental DNA metabarcoding. Mol Ecol. 25:929-942.
Ver Hoef JM, Peterson EE. 2010. A moving average approach for spatial statistical models of stream networks. J Am Stat Assoc. 105:6-18.

Ver Hoef JM, Peterson EE, Clifford D, Shah R. 2014. SSN: an R package for spatial statistical modeling on stream networks. J Stat Softw. 56:1-43.

Vörösmarty CJ, McIntyre PB, Gessner MO, Dudgeon D, Prusevich A, Green P, Glidden S, Bunn SE, Sullivan CA, Reidy Liermann C, Davies PM. 2010. Global threats to human water security and river biodiversity. Nature. 467:555.

Voulvoulis N, Arpon KD, Giakoumis T. 2017. The EU Water Framework Directive: From great expectations to problems with implementation. Sci Total Environ. 575:358-366.

[UN WWAP] United Nations World Water Assessment Programme. 2015. The United Nations World Water Development Report 2015: Water for a Sustainable World. Paris, UNESCO. http://www.unesco.org/new/en/loginarea/ natural-sciences/environment/water/wwap/wwdr/

UN-Water. 2015 Compendium of water quality regulatory frameworks: which water for which use? UN-Water. International Water Association (IWA) and the United Nations Environment Programme (UNEP). www.iwanetwork.org/which-water-for-which-use

Weigand A, Zimmermann J, Bouchez A, Leese F. 2017. DNAqua-Net: advancing methods, connecting communities and envisaging standards. Biodiversity Information Science and Standards. 1:e20310.

Whitehead PG, Wilby RL, Battarbee RW, Kernan M, Wade AJ. 2009. A review of the potential impacts of climate change on surface water quality. Hydrol Sci J. 54:101-123.

Wilby RL, Orr HG, Hedger M, Forrow D, Blackmore M. 2006. Risks posed by climate change to the delivery of Water Framework Directive objectives in the UK. Environ Int. 32:1043-1055.

Zaiko A, Daunys D. 2015. Invasive ecosystem engineers and biotic indices: giving a wrong impression of water quality improvement? Ecol Indic. 52:292-299. 